\title{
Forma Narrativa, Diálogo e Filosofia: a Inatualidade e o Presente em Schelling ${ }^{1}$
}

\author{
Anderson Gonçalves da Silva
}

\begin{abstract}
RESUMO: Não é incomum que se tome o diálogo de Schelling conhecido como Clara por um estoque de proposiçōes filosóficas, do qual se arrancam aquelas mais apropriadas para a tese que se queira sustentar. Procuramos nos afastar desse tipo de procedimento. Tomando seriamente seu tratamento literário, trata-se antes de investigar esse diálogo, apreendendo-o como um modelo, ensaiado pelo filósofo, para uma crítica do presente. Para tanto, analisamos a oscilação entre diálogo e narrativa, de modo a compreender sua composição e princípio formal, o que acarreta uma reflexão, interna à obra, sobre o tempo histórico, o qual se apresenta numa dialética entre inatualidade e presente.
\end{abstract}

PALAVRAS-CHAVE: Inatualidade. Presente. Narração. Diálogo.

Eu tive que roubar todo conteúdo à imaginação poética para dar conteúdo político ao materialismo da imaginação. (Bernard Desgaudrioles, apud Bento Prado Jr.).

A imagem da assim chamada Antiguidade clássica e de suas obras de arte, pelo menos desde o humanismo da Renascença, foi como que depurada do elemento ctônico e, em seu caráter geral, olimpicamente vista como "uma nobre simplicidade e uma grandeza serena" (eine edle Einfalt und eine stille Größe), de modo que suas figuras pudessem ser esteticamente apreciadas, aparentemente sem a sobrecarga do culto ${ }^{3}$. Esse lado obscuro, no entanto, não foi propriamente eliminado; pelo contrário, retornou, ou sobreviveu, em diversas formas e âmbitos ao longo da história. Tomemos um exemplo da

\footnotetext{
${ }^{1}$ http://dx.doi.org/10.1590/S0101-31732015000300005

${ }^{2}$ Professor do Departamento de Teoria Literária e Literatura Comparada da FFLCH, USP. E-mail: andergon@usp.br

${ }^{3}$ É preciso acentuar que as consideraçóes de Winckelmann sobre a arte grega antiga, bem como seus efeitos, não se restringiam à Alemanha, mas faziam parte de um debate europeu. Sobre isso, o número especial ("Écrire l'histoire d'art") da Revue germanique internationale, no 13, 2000. Quanto à reconsideração dessa imagem olímpica como que depurada do ctônico, tomando por base o Renascimento, cf. Warburg, 2013, p. 516-518, e Benjamin, 1984, p. 248ss. Quanto à frase citada, Winckelmann, 1990, p. 142.
} 
literatura alemá que tem precisamente como tema a linha divisória entre o olímpico e o ctônico.

Serenus Zeitblom, narrador do romance Doutor Fausto, de Thomas Mann, aplicando-se, nos primeiros capítulos, em encontrar a embocadura de sua narrativa - a vida de um homem, Adrian Leverkühn, dedicado ao "idioma dos sons" -, dá mostra do que pode aparecer como um "humanismo ambíguo ilustrado" em relação ao mundo mítico, ou seja, a dupla face olímpica e ctônica do narrador como "moderação e ferocidade" (JESI, 1977, p. 63; JESI, 2001, p. 200).

Inicialmente, Zeitblom se pergunta sobre a possibilidade de distinguir um limite entre "[...] o mundo nobremente pedagógico do espirito e aquele outro mundo dos espiritos" ${ }^{4}$ e, em seguida, seu questionamento insinua que não há o primeiro sem este segundo. A insinuação é confirmada pela breve narrativa de um episódio de sua viagem, ainda moço, à Itália e à Grécia. Essa imagem concentra a Bildung de Serenus, bem como seu papel social de professor de filologia:

Quando do alto da Acrópole dirigia o olhar à via sacra, pela qual avançavam os mistas ornados com a testeira de açafrão, o nome de Iaco nos lábios, e em seguida, quando me achava no lugar da própria iniciação, na zona do Eubuleu, à beira da fenda plutônica, sobranceada de rochedos. Eis o que experimentei pressentindo a plenitude do sentimento de vida que se expressa no fervor iniciatório da grecidade olímpica perante as divindades das profundezas, e mais tarde, falando da cátedra de meu colégio, amiúde expliquei aos alunos do último ano que a cultura consiste propriamente na conjunção piedosa e ordenadora - quase que se poderia dizer: propiciatória dos monstros da noite no culto dos deuses. 5

Da contemplação da procissão ritual dos iniciados dionisíacos, que, portanto, vieram de uma "formação" nos Mistérios, ele chega ao local em que se invoca Hades (Eubuleu é seu nome propiciatório, aquele em que por temor se lisonjeia e enaltece o deus em busca de favores), o deus dos mundos ínferos. Aqui ele se póe e permanece dentro do círculo do culto e dele conclui, como educador, que a cultura (o mundo do espírito) consiste no trabalho de ordenação e oficiamento do ritual ctônico; o mundo do espírito (cultura), sem

\footnotetext{
${ }^{4}$ Lembremos que há uma dupla significaçáo da expressão Geisterwelt, um mundano (mundo dos espíritos, sobrenatural) e outro acadêmico (mundo de espíritos, suprassensível).

${ }^{5}$ A citação, com pequenas alteraçôes, foi retirada da edição brasileira do Doutor Fausto (MANN, 1994, p. 15).
} 
autonomia, permanece "encantado" dentro do círculo mitológico. Na exposição de seu objeto, o pedagogo e narrador faz, portanto, com que o seu propalado humanismo desapareça; em vez de esconjurar o ctônico, ou antes o próprio paganismo, que o assusta na época de sua formação e durante a ascensão e estabelecimento do nazismo (quando escreve sua narrativa), Zeitblom o invoca. Em resumo, há de se notar que a distância narrativa se interverte em fusão cultual e a afirmação do humano se interverte em afirmação do inumano. Ou seja, as dimensôes estética e política se tornam ambas, em indistinção, o próprio mítico. Ora, a despeito de quaisquer boas intençôes de seu agente, é possível concluir não só sobre sua ineficácia, como sobre sua conjugação com os símbolos e a violência do poder. Nesse sentido, Thomas Mann, o escritor propriamente e náo o narrador, encara a face escura do humanismo alemáo.

A oposição entre olímpico e ctônico pode ser sintetizada com o termo "paganismo", o qual por sua vez pode ser contraposto a "cristianismo", o que permite nos voltarmos a Schelling e - aqui nosso objetivo - ao escrito Clara ${ }^{6}$. À primeira vista, é a história de uma jovem viúva católica que, auxiliada por dois amigos, um pastor protestante e um médico, tem por "aventura", na qual todos se engajam, seu trabalho de luto. É composto como um diálogo filosófico, seis fragmentos sobre a passagem do mundo natural para o mundo dos espíritos. As conversas são narradas pelo pastor. Em termos filosóficos tradicionais, trata da morte e da imortalidade da alma. É de nascença obra compósita e fragmentada. Parece um ensaio para desenvenenar a prosa filosófica dos vincos da vida acadêmica de um professor universitário de filosofia e aparece antes como ruínas significativas dessa tentativa de se bater contra a divisão social do trabalho. Noutras palavras, trata-se do interesse de Schelling pelo que chamou, em seu diário, de "Popularität" (SCHELLING, 1994, p. 145), isto é, uma prosa que fosse expressiva do tema já presente no "Mais antigo programa sistemático do Idealismo Alemão", a unidade entre intelectuais (Gelehrten) e povo, desdobrado, dentro de sua obra, em duas frentes: o modo de exposição narrativo trazido para a filosofia e o uso de expressóes e temas tirados da teosofia. Tal meta reaparece na empreitada schellinguiana de uma filosofia da história, nas Weltalter. Ali ele procura deslindar cientificamente as "representaçōes místicas" (mystische Vorstellungen)

${ }^{6}$ Clara (SW, IX, p. 03-110) é como se referem comumente, na bibliografia secundária, a esse texto de Schelling. No manuscrito original, consta apenas "Sobre a conexão da natureza com o mundo dos espíritos. Um diálogo. Fragmento" (Über den Zusammenhang der Natur mit der Geisterwelt. Ein Gespräch. Fragment). Sobre a data em que foi escrito, a discussão entre os comentadores varia entre 1809 e 1812. 
da teosofia. Mas, salienta Schelling, isso teria de ser uma "mania universal" (Allgemeine Sucht), o que só seria possível se a filosofia da época se empenhasse em fornecer "fundamentaçôes científicas" para tais imagens (Vorstellungen), em consonância com o pedido da "nação alemâ" para que a filosofia não desistisse. A fim de que tal aclaramento, uma tal empreitada esclarecida e esclarecedora ocorresse, no entanto, caberia se desfazer dos fumos de fidalguia perante essas representaçóes populares ou, na proposição imperativa de Schelling: "Não bancar o grande fidalgo" (Nicht den großen Herrn spielen) (SCHELLING, 1994 , p. 145). Noutros termos, por meio da cientificidade interna ao próprio conceito mundano de filosofia, busca-se superar a distinção entre o acadêmico e o popular, bem como ao que aí está suposto, a mera oposição entre conceito e imagem, no que se ausenta o verdadeiro intrincamento e complexidade da relação. Politicamente, Schelling encara a face obscura do sapere aude!, o que interrompe, salvo engano, certo conforto ideológico de simplesmente negar substância ou existência a essas representaçóes e a seus "conteúdos", como quem tomasse essa negação simples por neutralização efetiva.

Os comentadores, em geral, tomam Clara como um estoque de proposiçóes filosóficas, do qual retiram aquelas mais apropriadas para uma tese qualquer que queiram comprovar sobre a filosofia de Schelling ${ }^{7}$. Ou, ainda, fazem de Clara, no que não é estoque, um monumento memorial à esposa, Caroline, falecida em 1809. Pretendo, aqui, traçar um percurso diferente desse. Não será meu interesse analisar os temas propriamente; tenciono na verdade fazer uma espécie de análise formal de Clara, o que não implica desligamento da filosofia, lidando com questóes como: qual é a fisionomia do narrador? Como se dá e que consequências são possíveis depreender do entrelaçamento da temporalidade épica de uma narrativa com a temporalidade dramática de uma conversação? O que é possível expor dos personagens, dentro dessa forma? Caberia algum tipo de comparação com obras da literatura alemá? É com isso que nos pomos às voltas, com uma leitura de Clara. Uma tentativa de compreender sua composição. Caso não se leve isso em conta, sua construção compositiva, corre-se o risco de, por assim dizer, traduzir literalmente expressóes idiomáticas, ou cair em fintas.

\footnotetext{
${ }^{7}$ Só conheço propriamente uma exceção, o livro de Sara Nosari (1998), mas que me parece uma leitura equivocada, excessivamente marcada por um certo pathos da finitude.
} 


\section{1}

O narrador que, por profissão, é um pastor, mestre ou doutrinador, Lehrer, está autorizado a predicar, a convencer em favor de uma crença, mas não é desse modo que ele se póe em sua narrativa. No plano privado das conversaçôes, ele dialoga; no plano público da escrita, ele narra. Se dialoga, não cabe predicar. Se narra, o que faz então?

É curioso que, caso acentuemos o aspecto alegórico, conforme o esquema antropológico de Schelling no período, o médico representa o corpo, o pastor representa o espírito e Clara, a alma, o liame entre os dois. O que faz lembrar, embora não em perfeita correspondência, o célebre opúsculo kantiano, "Respondendo à pergunta: o que é Aufklärung?". Nos termos de Kant, temos um Seelesorger, homem que cuida e conduz as almas, e um médico, homem que ajuíza sobre o corpo de outros. Nos termos de Schelling, o médico seria um especialista na natureza (mais propriamente, um Naturphilosoph), enquanto o pastor seria um especialista no espírito. Ambos se ocupam com alguém em meio a uma crise pessoal, de modo a auxiliá-la a ficar de pé sobre as próprias pernas. Em parte, eles agem como especialistas, porém, tomando a distinção kantiana, não fazem uso privado da razão, não falam em nome de nenhuma instituiçâo. São seres racionais que pensam livremente sobre os assuntos de sua especialidade, estão como que desatados seja da "máquina" estatal, seja da Igreja. Portanto, os usos livre e universal da razão, em Clara, são manifestos pelo andamento e teor das discussóes. Quanto ao uso público, ele se daria na publicização da narrativa e mesmo antes, no próprio ato narrativo. Ao que parece, há um legítimo uso crítico da razão. Há, na verdade, mais que isso: há um comentário da empreitada crítica e sua época, da Aufklärung.

Ora, tomar Schelling por um iluminista, antes de mais nada, parece um perfeito contrassenso, com o qual é certamente impossível concordar. No entanto, tomá-lo como alguém que se ocupa com sua própria época, isto sim já é mais sensato. Schelling, na verdade, não faz nenhuma negação abstrata da Ilustração, e tampouco pode ser tido por um Schwärmer. A questão é que a representação schellinguiana de uma efetiva Aufklärung vem junto com um "princípio bárbaro" que, precisa o filósofo, "[...] vencido mas não aniquilado, é o embasamento de toda grandeza e beleza” ( $S W$, VIII, 343). Salvo engano, aqui se dá o enjeu político e estético desse escrito, na medida mesma em que a relação entre o princípio bárbaro e o Iluminismo constitui como que algo de precipitado da forma de Clara. 
Voltemos ao uso público da razão, e retomemos com outros termos a descrição geral de nosso texto: o pastor e o médico, duas figuras típicas do douto, se encontram com uma viúva, que carece de cuidados profissionais. No entanto, não ocorrem duas consultas. Pelo contrário, a rudeza da vida profissional, sua autoridade, é deixada de lado, pois o encontro é conduzido como conversação, civilizadamente apoiada em philía, de modo tal que a competência profissional desses dois homens abstratos, afinal são anônimos definidos pelo lugar que ocupam na divisão social do trabalho, se dá de maneira amadora - o poder religioso e o poder médico, ao que parece, estão suspensos. É um encontro polido, socialmente falando, entre dois burgueses e uma aristocrata. O que poderia se dar como uma luta, encontro de inimigos, dá-se conforme afinidade (cf. KANT, 2006, p. 73-74; VII, 176-7) ou Gesittung bons modos, boa criação, urbanidade. Evitam-se os extremos: nem exaltação mística, nem exaltação da "ciência pura". Evitam-se oposições extremadas: nem "imoralidade" da monarquia, nem "virtude" da república9. Pretende-se, portanto, uma conversação de que se ausentem radicalizaçôes. Contudo, a distinção jamais se apaga, ou mesmo é esquecida, já que a nobre tem nome, não os burgueses. A ausência de nome próprio possibilita tomar os dois, literalmente, como lugares-tenentes. Eles são representantes (Vertreter) que exercem funções, sem que os possam prender em determinações de conteúdo. Evocam com isso figuras como Asclépio, ligado à medicina, e Hermes, mensageiro e condutor de almas. Mas coloquemos o foco na condução, a atividade principal do narrador, para melhor caracterizá-la.

Pelas conversaçôes, Clara é conduzida e persuadida, em seu trabalho de luto, a conciliar-se com a natureza, pela qual, aliás, declara horror e a qual define como "[...] essa noite eterna, essa fuga da luz, esse ser eternamente em luta que nunca é" ( $S W$, IX, 27). O médico, por suas declaraçóes, algumas vezes quase exaltado, procura iniciá-la na filosofia da natureza. Pelos "ensinamentos", sabe-se que é preciso primeiro conciliar-se com a natureza para então elevar-se às significaçôes do mundo espiritual. Pelos signos funestos, que despontam ao longo da narrativa, e por alguns momentos em que Clara é descrita em estado de transfiguração (traços hipocráticos), sua morte é certa. O pastor chega

\footnotetext{
${ }^{8}$ Para uma análise magistral da Gesittung, ainda que especificamente relativa a Bachofen, cf. JESI, 2005, p. 04-57.

${ }^{9} \mathrm{Na}$ primeira parte do relatório de 07 de maio de 1794, apresentado em nome do Comitê de Salvação Pública, Robespierre expóe essa oposição, que serve de base para culminar no triunfo da Revolução e, com isso, estabelecer o culto do Ser Supremo e um "[...] sistema de festas nacionais" (ROBESPIERRE, 1999, p. 163-190).
} 
mesmo a comentar que, na noite de Natal, "[...] havia em seu ser, a noite toda, algo de transfigurado e uma espécie de serenidade indescritível, que há muito não notáramos nela” ( $S W$, IX, 41). Clara educa-se, e é educada, para tornar-se estranha à vida e familiar à morte. O narrador, portanto, conjuga diferentes formas de condução (psicagogia ${ }^{10}$, anagogia, mistagogia e pedagogia), quase como fosse uma composição musical em que o motivo (morte) é diferentemente retomado a cada punhado de compassos, mas o desenvolvimento não chega a um gran finale, uma vez que o leitor não tem acesso à hora mortis. Sem clímax, ocorrem repetiçóes que, a cada vez, produzem sentidos: tempos próprios e autônomos em correlação, e cada qual reproduz em si mesmo o surgimento do tempo. A promessa de morte, que acompanha a narrativa, não se cumpre como imagem. $\mathrm{O}$ arredondamento ou arremate não se cumpre. $\mathrm{O}$ inacabamento de Clara não é de todo incompatível, começa a se ver, com sua forma. É ao leitor, caso queira, que incumbe cumprir o prometido. Muito provavelmente, imagina-se, não seria um fim gorgônico à maneira do jovem Werther, tal como narra o "editor" das cartas: "Disparara na cabeça, acima do olho direito; o cérebro era expelido". Talvez Clara adoeça e, paulatinamente, vá minguando?

As aberturas dos dois textos, Werther e Clara, são quase uma oposição. A circunspecção de um passeio, no outono, por um cemitério se afasta fortemente da expansão lírica e sublime da primavera de Werther. "Uma serenidade maravilhosa”, escreve Werther, na segunda carta, “[...] ocupou minha alma inteira, tal como a doce manhã primaveril, de que desfruto com todo meu coração" (Eine wunderbare Heiterkeit hat meine ganze Seele eingenommen, gleich den süßen Frühlingsmorgen, die ich mit ganzem Herzen genieße). Serenidade que se reverte em aquiescência, uma vez que ele se abisma na beatitude do espetáculo da natureza: “[...] eu sucumbo ao poder violento da majestade desses fenômenos" (Ich erliege unter der Gewalt der Herrlichkeit dieser Erscheinungen). O início com a primavera juvenil e pânica, que aquece Werther, é promessa de vida - e promessa encruada de morte: um futuro junto com o sentimento sublime de ser aterrado. O outono de Clara é só promessa de morte; sua primavera ${ }^{11}$, em compensação, uma jubilosa promessa

\footnotetext{
${ }^{10}$ Inclusive em seu sentido platônico, em que se conjugam diálogo, dialética, retórica e política. Sobre o assunto, cf. Tordesillas, 2006, p. 293-306.

${ }^{11}$ Refiro-me ao fragmento "Der Frühling", editado no Nachlaßband das obras completas de Schelling (WA, 272-275). Anotado pelos editores, ali consta: "Projeto para a continuaçáo do diálogo Clara (início do quarto diálogo)". Esse fragmento foi publicado pela primeira vez em 1862, depois da primeira ediçấo das obras completas de Schelling. Só foi republicado em 1946 pela reedição das obras completas.
} 
de vida, mas apenas na medida em que ela cinde o instante, de modo que o tempo se inicia apontando para a vida como passado e para morte como futuro, o mundo dos espíritos. O presente de Clara é tensionado entre o passado e o futuro. Seu júbilo primaveril não se desliga, entretanto, da tristeza da natureza emudecida: "Ó primavera! tempo do anelo, com que vontade de viver preenches o coração!", "O Frühling, Zeit der Sehnsucht, mit welcher Lebenslust erfüllst du das Herz?" (WA, 272). O júbilo, aqui, note-se, é inclusive próximo do sentido agostiniano: a palavra coagulada que estoura e se estilhaça diante da Palavra falante, um elevar-se (sublime) que é rebaixar-se (bumilis). Em Clara, o pesadume, ou melancolia, puxa para baixo, enquanto o espiritual, para cima - sem que essa tensão se resolva, pelo menos inicialmente.

Para Werther, é difícil viver e é difícil morrer ${ }^{12}$. O gesto de Werther é gesto de renúncia, um sacrifício introvertido. Ele satisfaz o instituto jurídico e de fato abdica de seu amor por Lotte. Em seguida, mata-se. Todavia, o suicídio não é seu verdadeiro gesto, afinal, são doze horas de agonia, que, em alemão, aliás, se diz Todeskampf, luta de morte. Daí se pode dizer que não houve preparação exitosa para a morte. É preciso que a morte seja horrível, gorgônica, para que a renúncia, aqui fruto do direito, se espelhe nela. Aqui ninguém se liberta, talvez se tenha uma promessa de libertação, que começa como recusa, ainda que passiva. O sacrifício se faz mais evidente, na obra de Goethe, na figura de Margarida, principalmente a cena do cárcere: a aceitação do sacrifício de si, seu "destino", como gesto de revolta; a docilidade, passividade, se dá como autonomia que, ao mostrar-se, é esmagada ${ }^{13}$. A vida de Margarida se esvazia, e a morte, como vazio, acusa sem significado: uma denúncia vazia, portanto, e, por isso mesmo, surge esperança onde não há nenhuma. Não há preenchimento do futuro, mas uma antecipaçáo vazia. Em Clara, por sua vez, se é lícito falar em revolta, ela cabe ao narrador. Em seu procedimento, ele resfria a oposição dramática pelo distanciamento épico: ele mistura reflexão, que se ganha com o expediente épico, com a reflexão do diálogo dramático (e dialético) e ganha com isso uma forma pacificada, "civilizada", de resolução de conflitos. Formalmente, ele produz um drama apaziguado pelo gesto épico. O gesto de Clara é distinto, e não pode ser observado sem levar em conta o narrador. A fala de Clara, no fragmento "Primavera", se retesa inicialmente entre dois polos e, em seguida, é distensionada com a imagem da beatitude da alma, o liame vivo de corpo e espírito. Soa como um canto de despedida,

\footnotetext{
${ }^{12}$ Sobre o romance Werther, ver Jesi, 2000, p. 76-81.

${ }^{13}$ Sobre a docilidade (Fügsamkeit) como revolta, ver o ensaio "Parataxis" de Adorno (1975, p. 156-209).
} 
pois ela parece pronta e decidida a morrer. Para Clara, foi fácil viver enquanto casada; com a viuvez, interrupção do laço social do matrimônio, tornou-se difícil viver. Ela sobrevivia, mas sempre como quem estivesse prometida para a morte, desde que nos fiemos, é claro, no narrador. Terminado o fragmento "Primavera", é fácil morrer. Como se ela se dispusesse jubilosamente a ser sacrificada, a cumprir as expectativas que os prenúncios funestos do início outonal prometiam. Interrompe-se seu canto e o narrador descreve o apogeu da natureza, preenchendo a esperança do "eterno ressuscitar" da natureza, que despontava nas flores temporâs do outono. É quase catártico para o narrador. A personagem Clara invoca a morte e se resigna. Em Clara, não é escolhido o gesto de Werther ou de Margarida, não são sacrificados nem um burguês, nem uma moça das grandes massas. A aristocracia é quem deve ser sacrificada. O sacrifício é também um modo de pôr termo ao luto.

Se lembrarmos que a tragédia antiga (cf. BENJAMIN, 1984, p. 129-141) era parte de uma festa cívico-religiosa, na qual se comemorava a democracia, que nela se tem uma sequência de mortes que leva quase ao esvaziamento do palco e perfeitamente ao esvaziamento do poder aristocrático (morta a família real, não há continuidade do poder; basta pensar na família mítica de Édipo), que a tragédia antiga era um modo de retomar e repetir o gesto político da luta pelo estabelecimento da democracia (tentativa de interrupção da identidade entre símbolos míticos e símbolos de poder), é possível sustentar que esse gesto trágico é retomado, com as diferenças que apontamos, pelo narrador de Clara. A ação narrada de Clara é, nesse sentido, trágica: liberdade e necessidade coincidem na heroína. Contudo, sem a vida pública do teatro (nem a festa cívico-religiosa dos antigos, nem o coup de théâtre do classicismo), mas sim do mundo de leitores. Retomando os termos de Schelling, o presente só tem início quando o passado, princípio bárbaro, é “[...] vencido mas não aniquilado", de modo que possa tornar-se "[...] o embasamento de toda grandeza e beleza" (SW, VIII, 343). Não há beleza sem princípio bárbaro, assim como não há presente sem que o passado tenha sido vencido. Em resumo, na evocação sacrificial do narrador, salvo engano, está o mordente de Clara. Ele evoca e exorciza a morte, espécie de cumplicidade que, ao mesmo tempo, esconjura.

\section{2}

O narrador se faz condutor, regente que estabelece o andamento de toda a peça. Ele governa o todo e cada um. Seus expedientes não só introduzem como também conduzem o leitor em sua composição. Se a narração é um 
ato de memória que, como tal, interrompe a força e presença da morte, o distanciamento que se ganha, aqui, toma contornos paródicos. Lembremos do intermezzo irônico de nossa narrativa (cf. SW, IX, 86-92). Clara, na casa do pastor, vê um livro sobre a mesa. Ao folheá-lo, um livro de filosofia, lamenta-se:

Por que é assim impossível que aqueles que hoje filosofam não escrevam como falam, pelo menos em parte? Essas palavras artificiais horríveis são, pois, absolutamente necessárias? A mesma coisa não se deixa dizer de nenhum jeito num modo universalmente humano? E um livro de filosofia tem de ser inteiramente indigesto para que seja filosófico? (SW, IX, 86).

A conversa nesse trecho gira em torno de se escrever filosofia em formas acessíveis a qualquer pessoa cultivada; esse é um pouco o sentido de universal aí, bem à maneira kantiana do mundo letrado, Leserwelt, no opúsculo a que nos referimos acima. Chegam até mesmo a conjecturar que o romance talvez seja o sucedâneo moderno do que, entre os antigos, foi o diálogo. Passa-se de uma comunidade efetiva para uma "comunidade imaginada" de leitores. Clara, enquanto narrativa de um diálogo, é resposta a essa conversa. A ironia, então, náo se reduz a um piscar de olhos para o leitor, como quem diz "Eu consegui!" Não, a ironia se deposita, em seu sentido enfático, na forma, conforme a relação entre o épico e o dramático que descrevemos acima. É uma narraçáo e, enquanto tal, é uma evocação. Narra-se uma ação que, se é um sacrifício, protótipo do drama em sentido amplo, é uma invocação. Esta é uma participação, ao passo que a narração é distanciamento que, porque paralela à invocação que evoca, se faz também paródia: o ponto crítico por excelência e, nesse sentido, é uma pesquisa, uma exposição do tempo presente. Entre as implicaçôes dessa forma está o seu jogo dos tempos. Mas, para que isso se mostre melhor, releiamos a abertura de nossa narrativa. Insistamos, tudo se passa sob o signo da morte: outono, dia de finados, assiste-se à celebraçáo católica num cemitério. Isso que se vê e é descrito, o ritual público pelos mortos ou "a vida diante dos túmulos", interrompe a ação do narrador e de seu compagnon de route, o médico. Esse primeiro episódio tem por título "O pastor narra"; citemos a introdução narrativa:

No dia de finados, íamos à cidade, o médico e eu, para voltar à tarde com Clara, que já há alguns dias viajara para lá em companhia de minhas duas filhas. Do mesmo modo que tínhamos diante de nós a bela cidade, que ficava aproximadamente a meia altura da montanha, exatamente no ponto de visão de uma abertura, que dava para uma larga planície, nós vimos uma multidáo de pessoas se ajuntando e dirigindo-se para o 
lado de uma encosta suave. Logo presumimos aonde ia o cortejo e nos decidimos a assistir à comovente festa, celebrada nesse dia em cidades católicas à memória dos falecidos. Logo descobrimos todo o espaço ficar repleto de gente. Era um espetáculo singular ver a vida sobre os túmulos, pressagiosamente iluminada pelo sol de outono brilhando esmaecido. Visto que nos afastamos dos caminhos batidos, logo vimos uns bons grupos se ajuntarem em torno de diferentes túmulos: aqui, moças em flor, de mãos dadas com irmãos e irmãs caçulas, punham coroas no túmulo de uma mãe; ali, uma mãe de pé junto ao túmulo dos filhos que se foram cedo, onde não era preciso água benta para tomar o lugar das lágrimas, havia sim um pranto santificado que, vindo da doce melancolia (süße Wehmuth), caía suavemente e refrescava a terra da sepultura. Sérios e meditativos se mantinham os homens, aqui e ali, diante de diferentes sepulturas que talvez encerrassem um amigo que tenha ido embora cedo, ou uma amiga que não será possível esquecer. Todos os laços da vida lacerados se renovavam aqui para o observador, que conhecesse as pessoas e as circunstâncias; os irmãos voltavam para os irmãos, os filhos, para os pais e, nesse instante, eram novamente uma família; apenas a amada, de quem a morte roubou o amado, não podia mostrar-se nesse atropelo, talvez tivesse escolhido a manházinha para, sem testemunhas, com o orvalho matutino, umedecer com suas lágrimas o lugar que amava. $\mathrm{O}$ bonito monumento a um rapazinho, que morreu aqui como forasteiro, achava-se táo delicada e engenhosamente ornado com flores, que somente máos amantes o devem ter efetuado. "Quáo comovente é esse costume", disse meu companheiro, "e como é significativo esse ornamento de flores temporãs sobre os túmulos: e não é justo oferecer aos mortos essas flores de outono, que na primavera irão brotar suas flores alegres, para fora de suas câmaras escuras, em eterno testemunho da vida que perdura e da ressurreiçấo eterna?"

No meio do terreno, erguia-se uma capelinha, incapaz de conter a multidão. Logo depois de nossa chegada, ela ficara tâo repleta que uma longa fila, longe das portas, se havia formado por sobre as sepulturas. Nós nos pusemos ao lado de uma velha campa coberta de musgo, cujos traços já eram há muito ilegíveis, e escutávamos o ofício sendo celebrado, cujo andamento só podíamos acompanhar pelos movimentos daqueles que estavam do lado de fora. Nós nos sentamos absorvidos em serena melancolia (stille Wehmuth). Quantos dos que caminham aqui por sobre essas sepulturas irão repousar, neste mesmo ano, embaixo delas?

Por onde andaria nossa amiga? Acreditamos por um momento tê-la visto, mas sem a reconhecer realmente, ou podermos nos aproximar em meio à tropelia. Lembramo-nos que ainda tínhamos um bom caminho a fazer. Havíamos combinado com ela no mosteiro beneditino, situado numa colina do outro lado da cidade, onde em todo caso devíamos achá-la na hora da partida. Vimos que era hora, e nos afastamos em silêncio. 
Na cidade, encontramos tudo vazio e ermo; nós nos detivemos por um curto tempo, para nos refrescar um pouco, e subimos em seguida para o belo mosteiro. Na chegada fomos conduzidos à biblioteca, onde nos esperava um religioso, moço e bem-apessoado, que parecia ser encarregado de receber e entreter convenientemente os estranhos. ( $S W$, IX, 11-13).

Um traço marcante dessa abertura é o modo como se organizam tempos distintos, e isto é um procedimento de toda a obra. Passado, presente e futuro se entrelaçam; tempo privado e tempo coletivo se enredam. O narrador, diante da "paisagem", como que estaca e cisma. Não é o mundo natural que abre suas portas, uma vez que já são formas de artifício, entre as quais a vida se produz e reproduz; não há imediatamente uma contraposição entre aquele que observa e as formas naturais, anteriores a um estado civil. É antes um natural domado e domesticado que aparece diante dele. Tudo já parece em harmonia, conforme um provável agenciamento prévio; se há algo de propriamente natural, ele se contrai em enigma. Há a cidade e seu cemitério (vida e morte): um pedaço ou recorte do espaço que, cadenciado no tempo de uma viagem, é tomado como objeto do olhar e consideração do narrador. Junto com a cidade, à qual se segue uma planície, vê-se uma multidão que, aos poucos, se dirige em cortejo a um cemitério no dia de finados ${ }^{14}$. A delimitação do cemitério dá-se no povoamento pela multidão (Menge), categoria pré-política, se ajuntando à roda dos túmulos. Sua colonizaçâo se realiza pela ocupação bem ordenada das pessoas, seus arranjos de flores nas sepulturas, criando um primeiro nexo moral, a vida ética imediata (a família) entretecida em cordialidade, Gemüthlichkeit. E não à-toa, ocupando o meio do terreno, está a capela onde se realiza a liturgia; é por assim dizer o centro da comunidade objetivado, que, por sua vez, é vivificado pelos oficiantes. Os elementos fixos do cemitério, os túmulos e o que a eles se liga (Grab, Grabhügel, Grabstätten, Grabstein, Denkmal), imantados por essa disposição física e ética, são como que carregados de significaçáo ${ }^{15}$, a qual não se comunica. Como a

\footnotetext{
${ }^{14}$ Segundo a Legenda aurea, de Jacopo de Varazze, o dia de finados foi instituído por santo Odon (Odilon), abade beneditino de Cluny, no século XI. O feriado se liga ao purgatório (Fegefeuer), como purificação dos mortos, à oração dos vivos em favor dos falecidos e à intercessão dos santos pelas almas destes últimos (o dia de todos os santos é primeiro de novembro). A ordem beneditina, à qual pertence o mosteiro em que os personagens de Clara se encontrarão, foi fundada no século VI. Com seu principal centro em Cluny, uma primeira reforma da ordem, observando maior rigor na vida monástica, ocorreu no século $\mathrm{X}$.

${ }^{15}$ Como já indicamos, há no livro todo, retomado em dimensôes diferentes, um procedimento de acumulação de signos que só ganham alguma clareza com o decorrer da narrativa (por exemplo, o episódio do retrato, na primeira parte).
} 
natureza muda e triste, é o aspecto pitoresco e ruinoso de "[...] uma velha pedra tumular coberta de musgo, cujos traços já eram há muito ilegíveis", justaposto à observação do ofício, que desperta no narrador uma "[...] serena e quieta melancolia" (stille Wehmut), cujo resultado é uma breve interrupção da narrativa que se precipita na pergunta pelos que irão morrer. A linguagem das ruínas tem o mesmo pesadume (Schwermut) da natureza.

A festa, dia feriado em que estão suspensos os trabalhos cotidianos, apaga a vida material da cidade, deixando-a fora do alcance dos olhos. Os cidadãos livres da faina atuam e cumprem, oficiantes, a função política e religiosa (uma "ação simbólica”, cf. SW, V, 433-434) de restabelecimento dos laços da comunidade, conforme a solenidade de uma festa antiga ${ }^{16}$ : repete-se, em princípio, nesses instantes o ato de fundação ou criaçáo de uma coletividade, cria-se um centro que permite delimitar interno e externo, mas centro que permeia todas as partes, como uma Ideia mitológica. Uma visibilidade do que "vale a pena ser visto" e se dá a ver de maneira equivalente à Ideia. Nesse dia, a cidade dos vivos morre, para viver na necrópole. O que se vê, "a vida sobre os túmulos", presentifica a solidariedade comunal e evoca "pressagiosamente", tal como explicita o médico, com a imagem das flores e ressurreição, o futuro cumprido e redimido. Todavia, a um só tempo, o catolicismo é uma religião do passado: é a religião da aristocrata Clara. Apesar das arestas aparadas pelo narrador, resultado de seu proceder por Gesittung, há um curto-circuito nessa cena, do qual discretamente desponta certa ironia. Um pastor protestante narra a ação litúrgica da fé de um estado social (Stand), aristocracia, historicamente morto, caso se pense nos acontecimentos da Revolução Francesa. Se o que afirmamos sobre o papel de condutor do narrador tem validade, pode-se concluir que ele constante e rigorosamente se apascenta em função de fazer o passado tornar-se passado. Clara é um paradoxo: inatual e, no entanto, presente.

Contraposta à exposição pública da festa, aparece a imagem acanhada da "amada", em quem se prefigura a personagem Clara, visitando de manhã o cemitério. Prenuncia-se com isso que Clara, jovem senhora aristocrata, já não se confunde inteiramente com o passado católico, embora este não seja apresentado em estado puro. Esquemática e historicamente, o cemitério do mundo católico e do Antigo Regime seria como "[...] um resumo simbólico da

16 Para a questão da festa, baseio-me sobretudo em Karl Kerényi (1957, p.43-68) e Furio Jesi (2001, p. 81-120). 
sociedade" (ARIÈS, 1990, p. 547-548) ${ }^{17}$, de modo que a atitude característica dos homens diante da morte teria sido a de indiferença dos sentimentos, ao passo que a partir da Revolução Francesa predominaria um uso privado desse espaço, e a atitude principal estaria na afetividade exposta diante da perda. Em Clara, a presentificação narrativa da ação litúrgica (um passado) já é contemporaneamente "tratada" conforme a "nova sensibilidade" (ARIÈS, 1977, p. 11): o culto antigo configura-se com uma aurea mediocritas, e simultaneamente o cemitério é feito um lugar de passeio e meditação para o narrador, espécie de transformação do velho e abstrato jardim iluminista para dar lugar à espontaneidade da natureza (o pitoresco) ${ }^{18}$, bem como os sentimentos e laços familiares são ressaltados. Enfim, a despeito da possível comoção do narrador com a cena, a inatualidade da festa é posta. Ela é longínqua, um pouco à maneira de uma descrição científica, e mesmo sem eficácia, pois o narrador assiste ao ver, mas não vê o que veem. Evoca-se, em suma, como festa antiga, o inatual, no ponto de partida de uma reflexáo sobre o presente, ou antes, a narrativa de Clara é tentativa de estabelecer um presente. O pastor narra, uma vez que só se narra o passado, separado do presente. Nesse sentido, Schelling como que toma por mote um dito de Nietzsche sobre os alemães, [...] eles são de anteontem e de depois de amanhã - eles ainda não têm hoje" (NIETZSCHE, 2000, p. 132). Em outras palavras, eles são do tempo mítico e do tempo escatológico - eles não têm presente.

Voltemos à inatualidade de Clara. Pelos sinais funestos e pelo não-seiquê de transfiguração, é uma estrangeira entre os vivos. É solitária, porque já

\footnotetext{
${ }^{17}$ Tomo por base, principalmente, os capítulos X ("O tempo das belas mortes") e XI ("A visita ao cemitério") $O$ homem diante da morte. A pesquisa de Ariès se restringe à França e ao mundo anglosaxão, o que não impede a percepção de semelhanças entre o que ele descreve e o trecho inicial de Clara. Além disso, resumindo o argumento que nos interessa aqui, e sendo historicamente mais preciso, Ariès relata a passagem de uma prevalência da "administraçăo policial" (salubridade e higiene pública), associada a uma "vocaçáo civil" (p. 548), a uma preponderância da função privada (afetiva) no uso do cemitério. Em texto escrito em 1969, também sobre essa mudança de atitude diante da morte, pondera Jesi (2000, p.10): "O exercício da memória torna-se de fato luta contra a morte, busca desesperada de um vínculo com a eternidade que seja estranho à morte. Basta pensar num exemplo facilmente verificável: no mundo ocidental moderno a prática de visitar os cemitérios é agora freqüentemente motivada pelo desejo de alimentar a recordação dos defuntos. O túmulo perdeu inteiramente seu significado de lugar posto no limiar do Além, de ponto de intersecção entre reino dos vivos e reino dos mortos, para tornar-se apenas estímulo da memória; o atual costume da visita aos túmulos está exatamente em oposição ao antigo culto dos defuntos: a sepultura é agora valorizada em oposição à morte, como socorro da memória que combate a morte".

${ }^{18}$ Ariès estabelece o seguinte desenvolvimento, que vai do século XVIII ao XIX, do passeio como lazer público: primeiramente, os jardins, que são base para os cemitérios, que, por sua vez, são base para os parques (ele dá o exemplo do projeto e realização do Central Park de Nova Iorque).
} 
não participa inteiramente das relaçôes com os vivos. O que parece ser seu único vínculo erótico a liga à morte, seu marido morto, Albert. Sua fidelidade a faz íntima da morte. Seu alheamento - quase atopia, limiar entre o vivo e o morto - já é algo do demoníaco (das Dämonisches). Clara quase que só convive com os mortos e consigo mesma. Na convivência com os vivos, Clara é demoníaca: nem a vida nem a morte a possuem univocamente. O demoníaco é nomeado alma (Seele): "alma espiritual", na morte; "alma corporal" (leibliche Seele), na vida $(S W$, IX, 52); "[...] o espiritual do físico e o físico do espiritual" ( $S W$, VII, 476). O demoníaco aí aparece na agonia, na luta de morte. A morte, por assim dizer, propriamente subtrai, a Clara, a presença de Albert, seu marido; já esse despontar do demoníaco aparece como preparação para o futuro. Sob a conduçáo do narrador, marcada por ironia e paródia, Clara, como "aquilo que passou", deve morrer.

Ao nos pormos à roda de Clara, tentamos puxar os fios que possibilitassem a construção dessa forma. Clara é um modelo, ensaiado por Schelling, para tornar acessível seu presente, autônomo em relação ao seu "ontem" e ao seu "amanhâ".

SILVA, Anderson Gonçalves. Narrative form, dialogue and philosophy : inactuality and the present in Schelling. Trans/Form/Ação, Marília, v. 38, n. 3, p. 57-74, Set./Dez., 2015.

\begin{abstract}
It is not unusual that Schelling's dialogue known as Clara is taken for a stock of philosophical propositions from which one may pluck ideas appropriate for the thesis one wishes to defend. In this article, we try to move away from this type of procedure. Taking Schelling's literary treatment seriously, our purpose is to investigate this dialogue by looking upon it as a model, put forth by the philosopher, for a critique of the present. We therefore analyze the oscillation between dialogue and narrative in Clara in order to understand its composition and formal principle. This oscillation entails a reflection on historical time and presents a dialectic between inactuality and the present.
\end{abstract}

KEYWORDS: Outdatedness. Present. Narration. Dialog. 


\section{REFERÊNCIAS}

ADORNO, T.W. Parataxis: zur späten Lyrik Hölderlins. In: Noten zur Literatur III. Frankfurt: Suhrkamp, 1971. p. 156-209.

ARIÈS, P. História da morte no Ocidente: da Idade média aos nossos dias. Rio de Janeiro, Francisco Alves, 1977.

. O homem diante da morte. 2. ed. Rio de Janeiro: Francisco Alves, 1990, v. 2.

BENJAMIN, W. Origem do drama barroco alemão. São Paulo: Brasiliense, 1984.

JESI, F. O mito. Lisboa: Presença, 1977

. Spartakus. Simbologia della rivolta. Torino: Bollati Boringhieri, 2000.

. Materiali mitologici. 2. ed. Torino: Einaudi, 2001.

. Bachofen. Torino: Bollati Boringhieri, 2005.

KANT, I. Antropologia de um ponto de vista pragmático. São Paulo, Iluminuras, 2006.

KERÉNYI, Karl. Qu'est-ce que la fête? In: . La religion antique. Genebra: Georg, 1957. p. 43-68.

. Von Wesen des Festes. In:

Antike Religion: Werke in Einzelausgabe. Wiesbaden: Langen/Müller, 1978. v. 7, p.43-67.

MANN, T. Doutor Fausto: a vida do compositor alemão Adrian Leverkühn narrada por um amigo. Trad. de Herbert Caro. Rio de Janeiro: Nova Fronteira, 1994.

. Doktor Faustus. Berlin/Darmstadt: Deutsche Buch-Gemeinschaft, 1955.

; KERÉNYI, Kl. Gespräch in Briefen. Zürich: Rhein-Verlag, 1960.

NIETZSCHE, F. Além do bem e do mal. São Paulo: Companhia das Letras, 2000.

NOSARI, S. La favola di Clara: paradigma schellinguiano e pedagogia della morte. Milão: Mursia, 1998.

ROBESPIERRE, M. de. Discursos e relatórios na Convenção. Rio de Janeiro: Contraponto: EDUERJ, 1999. p. 163-190.

SCHELLING, F.W.J. (SW) Schellings Werke. Ed. de Manfred Schröter. Munique: Beck, 1959.

. (WA) “Der Frühling” Entwurf zur Fortsetzung des Gesprächs “Clara”. In:

Die Weltalter: Fragmente. Munique: Beck, 1979. p. 272-275.

Philosophische Entwürfe und Tagebücher 1809-1813: Philosophie der Freiheit und der Weltalter. Ed. de L. Knatz, H.J. Sandkühler e M. Schraven. Hamburgo: Felix Meiner, 1994. 
TORDESILLAS, A. Platone e la psicagogia. In: MIGLIORI, M et al. (Eds.). Interiorità e anima: la psychè in Platone. Milano: Rusconi, 2006. p. 293-306.

WARBURG, A. A antiga profecia pagã em palavras e imagens nos tempos de Lutero (1920). In: - A renovação da Antiguidade pagã: contribuiçóes científico-culturais para a história do Renascimento europeu. Rio de Janeiro: Contraponto, 2013. p. 515-621. WINCKELMANN, J.J. Réflexions sur l'imitation des oeuvres grecques en peinture et sculpture. Paris: Aubier, 1990. Edição bilíngue.

Recebido / Received: 05/03/2015

Aprovado / Approved: 02/04/2015 
SILVA, A. G. 